\title{
EFFECTS OF THE RELIGIOUS SOCIALIZATION LEADING TO OR SLOWING DOWN SUICIDE
}

\section{Summary}

The individual biography is relevant to the relation between suicide and religion. The religious socialization can have an indirect influence on the origin of a suicide crisis and on the way both young people and adults deal with solving this problem. This is the outcome of an empirical-theological research into seven case-studies. In connection with physical, psychological and social factors, the effects of the religious socialization cause, at worst, an individual lack of being fully aware of possibilities, situations and actions or of interpreting them realistically and act as the problem requires. At best, they encourage the search for possibilities to solve the oppressing problems adequately, by supporting the critical openness for the purpose of a process of finding the meaning of life.

\section{Introduction}

For decades, we have found that in psychology in general and depth psychology in particular, the human biography has been the origin of many psychic disorders, but also the starting point for therapeutic healing. In recent times, in pastoral ministry, its relevance has grown. This process is influenced by theology and psychology coming together in a mutual learning process, and by pastors utilizing the opportunities, which are implied in depth psychology, in their pastoral work. From a pastoral point of view, the individual biography can be seen as the origin of human evil, but also as the fountain of liberation. For example, life crises leave clear traces in individual biography. Factors which often stimulate, reinforce or cause these crises, can be reduced to large parts of the individual biography. Events which disturb human potentials and put them at risk, are to be considered from the total lifehistory's context (cf. Dömer \& Plog 1992, 10). One of the most extreme cases of this kind is suicide. In this article, we would like to clarify the relation between suicide and religion and try to localize it in the context of the individual's biography. 
Many factors are relevant to the developing suicidal crisis. It would take us beyond this article to list and clarify them all. From suicidological literature up until now, modern suicide research tries to take the religious factor into account. It did not discover direct causal relationships, thus proved religiosity to be a dispositional factor for suicide or attempted suicide (cf. Schmidtke 1988, 281-91/403-4; Hole 1977; Ringel 1989, 54; Reiner 1974). The question is, however, whether religiosity has been used adequately in all these investigations, in the sense that all the important variables and the interactions between various variables have been taken into account. If it is true, that suicide is highly likely, only 'if self-accusation, self-surrendering and other self-damaging life practices that reduce an individual's ability to act, are present in a culture' (Schmidtchen 1989, 34), then it is up to practical theology to deal with this impediment to human development, by means of theoretical aspects of action. If church workers want to support people in the pastoral practice, in guarding their integrity, or in developing it from their faith in a God, who wants nothing more than man's individualization in the face of the Kingdom of heaven, then theology, in particular practical theology, has to strain every nerve to make closer investigations into the obstructing and damaging aspects of the opportunities of life and existence of every single person from the perspective of theology. To that end, we have chosen the poimenic point of view, instead of the moral-ethical one as is done so often, in order to contribute to bringing light into the many dark dead ends of life, and to find out why people are actively and systematically working at their own destruction. (cf. at the same place, 15-6; Funke 1993, 182).

In a preliminary investigation of the empirical-theological research project 'Communication during the suicide crisis from a philosophical and a religious perspective', which is carried out at the Catholic University of Nijmegen at present and is supported by the Dutch Foundation for Philosophy and Theology (SFT/NWO), we came upon an aspect, which seems to be important within this context: the religious socialization. Seven people each had an extensive interview and, with the help of a qualitative interview analysis, these interviews were analyzed on trace elements of the religious socialization. Our definition of a problem was as follows: what is the meaning of the religious socialization for the suicide crisis the interviewed people find themselves in?

The qualitative research method that was used, did not need a large number of cases, for establishing, in particular, a theoretical value, besides a heuristic one. The article that is discussed here, wants to make a contribution from a practical-theological perspective to the development of a theory of the suicide prophylaxis, which does not guard people against their final step, but places them in touch with things and tries to give them a passion for being, in order to find their meaning of life (cf. Schmidtchen 1989, 100). The first paragraph 
first discusses the concepts of the suicide crisis and the religious socialization on which this research has been based, and on their connections (1). In the second paragraph, the seven interviews are examined for trace elements of the religious socialization (2). The third paragraph attempts to come to a conclusion and to evaluate the research results in a practical-theological way (3).

\section{The religious socialization and the suicide crisis: theoretical conside- rations}

The suicide crisis and the religious socialization are two concepts that can be defined in many ways, and which require a more accurate description and explanation beforehand. The suicide crisis will be discussed first (1.1), followed by the religious socialization (1.2), before finally focussing on the connection between the two concepts (1.3).

\subsection{The suicide crisis}

There have been many theories and definitions on the subject of suicide, which have been tested empirically and quite often been rejected or adapted. Meanwhile, one thing is undisputed: suicidal behaviour is a multi-dimensional problem, instead of an endogenous one, which should be understood differently in individual cases. Particularly important are the individual predisposition, the contingency of the situation and the social structure. In this research, we have deliberately selected the concept of the suicide crisis, because it not only includes the people who have made a suicide attempt, but also those whose tendencies to injure themselves have already developed into seriously contemplating suicide. The broadening of this concept is very meaningful for this practical-theological research directed towards prevention. The more so, because we can assume that tendencies to injure oneself have an effect on one's conduct (cf. at the same place, 53). On the basis of this assumption, we have decided not to make a distinction between para suicide and unsuccessful suicides (cf. Schmidtke \& Schaller 1992, 109).

Suicide should be seen as the result of a process of weighing pros and cons against each other, which is under the influence of a crisis. Crisis can de defined as a situation, in which a person no longer disposes of an action in his stock of conduct, of which he can expect, that it will lead to the realization of an objective strongly desired. The psychologist Diekstra describes the crisis as a situation in which a person

a) is confronted with a problem, which, by defintion, cannot be solved in the immediate future, whereas at the same time, 
b) the problem surpasses a person's psychological powers, because it is beyond the grasp of his usual problem-solving strategies. Moreover,

c) the situation is regarded as a threat to one or several objectives in life.

d) The crisis period is characterized by an increase in internal tension, rising up to a specific maximum and then dropping,

e) due to feelings of help- and hopelessness and

f) due to a larger degree of being impressionable.

g) During this period, recollections of earlier solutions to problems become vivid again. Time and again, 'trial-and-error' solution methods are deployed, the failure of which has already been preconditioned.

The specific aspects of a suicide crisis can be described by both an aspect of value and of expectation. It is connected with the highest and most important objective to be found in the hierarchy of values of the person concerned, at a specific moment in time and in a specific situation. If the person becomes fully aware of the unattainableness of the pursued objective, the crisis continues to be driven towards its climax. Only an action from the stock of conduct is felt to be most effective, in order to attain the objective that is given preference to (and therefore the solution of the present crisis) in a direct or indirect way: in this case, it can lead to a suicide attempt. The reflections on the execution of a suicidal action are linked up with the expectation with regard to the effectiveness of the suicidal action, as a means to solve the present crisis. These expectations are closely connected with experiences of earlier suicidal conduct or similar behaviour of other people in the same situation. The reactions of the environment also play an important part here (cf. Diekstra 1973, 108-29; 1984, 65-6).

This interactive explanation model allows a fair description of the multidimensional, causal process development of a suicide crisis. It is given preference to other starting points, first of all, because it offers the opportunity for other supplementing theories to be largely integrated, secondly, because it is well-founded on the action-theoretical starting point of this practical-theological research and thirdly, because it leaves out the idea of an illness.

\subsection{The religious socialization}

Within the primary and secondary socialization, the religious socialization creates an aspect, which can never be looked at, detached from its general 
context. That is the reason we will not be able to get around continously referring to this general context of the religious socialization.

\subsubsection{The religious socialization within the framework of primary and secondary socialization}

Socialization in general and the religious socialization, in particular, are of fundamental importance to man. With the help of socialization, man can find access to his social environment, with which he must leam to associate, if he wishes exist in it. He needs it in order to survive, because man, as a creature with little instinct, has to rely on guidelines for actions. He also has the opportunity to create his own environment. In the process of this, he is, first of all, dependent on his nearest contact persons, which are usually his physical parents. Through his parents, together with them and by opposing them, the growing child learns to familiarize himself with his environment and to discover his own viewpoints. In this way, the child develops an identity of his own in long phases and processes. The upbringing by the parents and the interaction with them, therefore create fundamental elements of the socialization. This is particularly applicable to the primary socialization at the first stage, when the child is introduced into his environment by his contact persons and becomes a member of this society. However, further on in life as well, there are events, during which the already socialized person is made familiar with new areas of reality of his environment and society. In this secondary socialization, the upbringing and interaction with the parents gradually play a smaller part (cf. Berger \& Luckmann 1987). The primary socialization, within which, if neccesary, the primary-religious socialization takes place, as well, characterizes itself as the first stage of socialization, as the child internalizes everything as a matter of fact and thus contributes his knowledge to the secondary socialization. 'During the primary socialization, the child does not look upon his important other people as 'officials' of institutions, but simply as intermediaries of reality. He internalizes the world of his parents as the world, instead of a world, belonging within a particular institutional connection. Some of the crises that occur after the primary socialization, do actually come from the awareness that the world of the parents is not the only world [...].' (at the same place, 152) Trust and obvious order define the child's first world, for it is not until later that man can afford the luxury of doubt. Since socialization is, however, a dialectical process between adaptation and self-assertion, it is up to the parents, on the one hand, to support their children in acquiring greater independence, to make the children competent to enter into social connections, without, on the other hand, neglecting their correcting and confronting function (cf. at the same place, 148-50; Dörner \& Plog 1992, 105-6). The way of upbringing and interaction is crucial in this respect. It determines, among other things, the degree of attention the children experience and what 


\section{EFFECTS OF RELIGIOUS SOCIALIZATION ON SUICIDE}

demands they have to face. Are those demands great or poor? Do these demands possess a specific correcting function or an arbitrary regulating one? The secondary socialization stage, within which, if necessary, also the secondary-religious socialization takes place, is characterized by continuous new impressions influencing the growing child, the young person and the adolescent. Life in modern western society forces those growing up in it to choose, so that they can obtain a picture of their own of their environment from the jumble of the manifold 'offers'. They have to acknowledge that many things, which they have taken for granted until now, have to be 'understood' anew, as there are countless new viewpoints for observing the world and life. This is also true of religion, respectively world views. Man has to make a choice in relation to his idea of faith, because religion has also lost its naturalness (cf. Berger 1980, 39-45).

\subsubsection{Religiosity as a product of the socialization by others and by oneself}

Both socialization stages are characterized by two forms of socialization: the socialization by others and by oneself. The socialization by others is the passing on of generally acknowledged convictions, values, standards and roles of society to the growing child by the parents and the future second educators. The socialization by oneself, on the other hand, is characterized by the adoptation of the transferred and passed on convictions, values, standards and roles of society by the child itself. In relation to the religious socialization, on which the same conditions are applicable, it means, that faith, ethos and spirituality are, on the one hand, passed on by the parents and, on the other hand, adopted by the children. As a result, there is an alternation between the socialization by others and by oneself in the primary-religious and secondary-religious socialization, in the process of which, the socialization by others, quite naturally, takes a somewhat more dominant part in the primary-religious socialization, whereas the socialization by oneself dominates in the secondary-religious socialization. When getting older, the growing child tries to enforce a socialization by himself, in order to strengthen his personality, and to serve as a counterpart of the socialization by others. This can obviously lead to the fact that convictions, values and standards are no longer simply adopted, as children, young people and adolescents dissociate themselves from them, select and transform them, so that, if need be, changed or new convictions, values and standards dominate within a religious community. The religious socialization is therefore a dialectical process of socialization by others and by oneself within the primary and secondary-religious socialization, which together create both sides of a coin 'of the private perception of the environment from which the religious person creates his development and being', and, consequently, the personal religiosity can be looked upon as their product. Following the social-cognitive theory of leaming by Banduras (1979), Grom (1992, 30-45) 
describes the social influences that contribute to the construction, change and preservation of a specific religiosity, in the form of learning by means of the model, learning by instruction and learning by the increased influence of others and social confirmation. The socialization by others encourages the socialization by oneself: examples (Jesus Christ, saints, parents, teachers etc.) of religious actions and sentiments make one curious, cause attentiveness and challenge imitation. Instructions and religious education give food for reflection. Material and social advantages, traditions and rules, the membership of a group and representation of interests, like-mindedness and confirmation support, demand and legitimize self-initiated conduct. Against this background, the religious socialization can be seen as a religious communication process, in which an individual can create and develop his private religiosity with the help of religious metaphors, symbols and pictures during the primary and secondary socialization (cf. Van der Ven 1993, 122). Religiosity is here regarded in an anthropological-onthological way, where the individual is moved by religiousness, and where faith is a theological concept for the subjective power of expression of this emotion, in the sense of the actions of faith (fides qua creditur) and the contents of faith (fides quae creditur). In most cases, the child will first adopt the religiosity and faith of his contact persons, insofar as they acknowledge a religion and faith themselves. It starts to change with the influence of the secondary socialization in school, youth groups and circle of friends. During the primary-religious socialization, the parents, in particular, are of great importance, because they can provide or prevent the foundation for a religiosity, organized in whatever form. Furthermore, they can support or obstruct, respectively, prevent the religious influences of non-relational second educators during the secondary-religious socialization (cf. Grom 1992, 20-3/30).

\subsubsection{Religion as an experience during the establishment of a meaning of life}

What is actually the specific meaning of the religious socialization? 'What' is being transferred through the religious socialization? 'Religion means the general human relation with the secret of transcendency, the bond with the establishment of a meaning of life, from which man can live and die.' (Schlette 1966, 12). This establishment of a meaning of life is transferred through the religious socialization. Religion is seemingly the experience with the finite of this meaning of life and, thus, man's confrontation with his own limitations and possibilities. Man's desire for perfection and fulfilment of purpose becomes clear, here. It is therefore not surprising that from the start, man tries to incorporate his desires, fears and hopes, which he experiences in his encounter with this transcendental meaning of life, in cults, rites, religious laws, holy scriptures, signs, places, stories and actions. This way, his religiosity keeps its form (cf. Tillich 1975, 22-5; Schlette 1966, 13). The child is 
made familiar with these forms, which radiate authority owing to a long tradition and special ritual. Through the transference of the parents or other contact persons, the child becomes acquainted with another, over-organized world. The child thus comes in contact with the God of his parents, who is at the same time phenomenal and inaccessible, a mystery, at the same time fascinating and frightening. To the child, religion becomes a meaningful system of purpose, connecting everything, which possesses an absolute identity and a system of standards to guide actions. The child learns to place every-day experiences in this meaningful system of purpose and to derive from it a way of conduct for himself. It is obvious that particularly the image of God plays an important part in connection with this. The very first anthropomorphic image of God influences the childlike model of attribution and the proces of socialization by oneself, because it exerts an incredible 'power', which offers the child, on the one hand, security and on the other hand, fills him with fear.

\subsubsection{Summary}

Against the background of the explanations so far, the influence of the religious socialization on the growing child can be summed up in three points: first, during the socialization, the child is dependent, besides his individual disposition, on the transference by the parents and other contact persons. The transferred world is at first, beyond any doubt, the only real world for the child. Secondly, the religious socialization also leaves its mark on the development of the child's identity. Once again. it are, primarily, the parents, in future however, gradually other contact persons, who hold an important position here. Gradually, the socialization by oneself takes the place of the socialization by others. The religious socialization has such an impact on the child and his development, that as he is,thirdly, made familiar with the meaning of life and existence, which, together with the sentiments, motivations and convictions, passed on by religion, it possesses a qualitative meaningful identity.

\subsection{The effects of the religious socialization on the suicide crisis}

What does the religious socialization mean to the suicide crisis? In connection with many physical, psychological and social factors, socialization in general, and the religious socialization in particular, have a decisive share in the development and increase of an individual's physical and spiritual opportunities for survival. The history of socialization of every individual is, based on the alternation of socialization by others and by oneself as described above, of vital importance for the identity, abilities and possibilities of the individual and for the communication and association with others. In case of an excessive reinforcement of others during the primary, but also the 
secondary socialization, the individual has to reckon with handicaps, which, in the long run, can express themselves in real symptoms of deficiency. Children, whose sense of self-respect has not been encouraged or suppressed, grow up as selfless beings, ruled by others. They themselves grow silent. All they do is react. They are focussed on the wishes of others. Consequently, they have to suppress their own desires. The way of upbringing and interaction of the parents is responsible for the fact that children create a sense of self-respect and talents, which are a person's internal potential and a condition for the development and change of one's own ideas. The sense of selfrespect and the richness of talents are guarantees that the child, the young person, but also the future adult can 'construct' a stock of possibilities for action, based on their self-consciousness and their identity, which they have acquired in the process of the socialization phases, with which they can link up the positive expectation, that they can adequately solve situations and problems in their life. Part of this stock is, among other things, the competence to communicate. The ability to express fears, desires and hopes, assumes that the individual has enough self-consciousness to discover them within himself and to bring them up with others. By means of its socialization effects, socialization has an influence on the potential possibilities an individual possessses on his path of life. This is also true of the effects of the religious socialization. Usually, the socialization effects of the religious socialization have an indirect triffering/encouraging or restricting impact on the socialization effects of general socialization: the children's image of God is developed from the dependence on the image of man, which they have acquired during their upbringing by their parents, and which marks the children's identity (cf. Grom 1992, 173-86; Jaschke 1992, 21-30; Funke 1993, 18). Following Grom, Oberthür $(1989,29-33)$ has developed a model for the creation of an image of God and a relation with him, in which the relation with the parents and the sense of self-respect are the most important factors. In addition, the cognitive development, the education about God and his relation to man, the religious practice and the relation with the other contact persons and groups, play an important part.

Whereas the image of God has a great impact on the growing child as a meaning of life and existence, it is usually also important for the future adult. The image of God is frequently included as a final authority in the upbringing and interaction of the parents. The image of God, passed on by the parents, often reflects their way of upbringing and interaction, or support it positively. An image of God and man which is too strict, can in connection with the right way of upbringing and interaction, lead to psychological disturbances: if the child does not succeed, due to the way of upbringing and interaction, in constructing and changing the image of God and man into his own self-image, without any conflicts and in harmony, this can lead to a mechanism of discord, which can again lead, at worst, to disturbances of 
personality. All reality is experienced as being unbearable. In a case like this, for instance, the image of the rejecting mother or that of the punishing and judging God, are separated from one another, while pushing the negative aspect from the mind, for fear of losing the 'good' image. It is no longer possible to experience the reality in its whole complexity. A person's identity should protect itself from further influences, in order to preserve what is thought to be available. Denial, projection, idealization and devaluation are the defence mechanisms resulting from this (cf. Funke 1993, 18-20). A person very rarely succeeds in discarding the old, distressing image of God and in gaining a new, liberating and humanly-friendly one. In most cases, the old image of God is repressed, although without losing its effect subconsciously. So, the image of God and man is, beyond any doubt, an effect of the religious socialization and exerts its influence through the sense of selfrespect, self-consciousness and the richness of talents, on the future adult's competence to act. What part do the effects of the religious socialization play on the suicide crisis?

As has been explained above, the essence of the suicide crisis is the attempt to solve, as well as possible, a problem which is gradually becoming more existentially important. People who find themselves in a suicide crisis do not usually dispose of the appropriate possibilities for solving problems. Why do they lack sufficient possibilities for taking action? Not seldom does this lack of possibilities find its origin in the socialization history, respectively, the socialization effects. 'Psychological crises, which lead to suicide at an advanced age, have a past history, usually going back as far as one's youth. The suicide personality has been developed during one's younger years, and has struggled with its problems over the years and decades, has remained inconspicuous, but when the burdens increase over the years, the personality system does not hold out.' (Schmidtchen 1989, 10) What is described here in few words, though very much to the point, touches upon the origin of many suicide crises, in which 'grown-up' men and women find themselves. People with marks of indifference, cold-heartedness, helplessness and stipulations by others, are deprived of their potential possibilities in life. They fight their way through life, develop techniques and strategies, in order to even up their 'socialization handicap', so that the effects of the religious socialization can have a major influence, in case they contribute to the roots of this handicap, encourage it or reduce it. In other words: the effects of the religious socialization create a factor, which should not be underestimated in the process of the development of a suicide crisis, in the training of an individual competence of action and in a possible intervention. The religious socialization can therefore possess, on the basis of, respectively owing to, its socialization effects, either a suicide encouraging or a suicide preventing influence. 


\section{The religious socialization and the suicide crisis: an empirical search for traces}

After we have focussed on the theoretical connection between the religious socialization and the suicide crisis, it is time to try and make this theoretical connection empirically visible in the second paragraph. To that end, we try to track down the trace elements of the religious socialization in the suicide crises of the seven people that have been interviewed. First of all, the phrasing of the questions, the conditions and the research method are discussed (2.1), before looking more closely at the experiences of the interviewed people with their own religious socialization (2.2) and the socialization effects of this religious socialization on the specific suicide crisis (2.3).

\subsection{Qualitative interview analysis}

In the formulation of the problem, there was an inquiry after the importance of the religious socialization on the suicide crisis, in which the interviewed people find themselves. Against the background of the theoretical discussion on the connection that is to be investigated here, we have selected two research questions: Is religious socialization, at the time of the interview, that existentially important to those interviewed, that they themselves turn it into a central issue? What part does religious socialization play in connection with the suicide crisis, for those that turn it into a theme?

The seven interviewees were from the Federal Republic of Germany and had made at least one suicide attempt, or had seriously contemplated one at the time of the interview, and were themselves now asking for professional help. Fears that only very strict church-going Christians and those firm in their belief would be prepared to take part in the interview within the framework of an empirical-theological research, turned out to be unfounded. The seven interviewed people are six women and one man between 30 and 70 years old, who, on the one hand, have experienced in their therapy/counseling, the importance and benefit of talking about their crisis situation for them and, on the other hand, were curious about the interview with a theologian, who wanted to discuss the experiences they had had in connection with the question about the meaning of life during their suicide crisis. Six of the interviewees are members of the Roman-Catholic church and one is a member of the Protestant church. Five of them have a primary-school education and following on from that, vocational training or further education and two have got an academic degree. Five of the interviewees come from families blessed with many children. Six of the interviewees have at least one child themselves. The interviews were recorded on tape, transcribed and then input to the computer programme 'Kwalitan'. This programme, developed by the socialscientific faculty of the university of Nijmegen in support of the research, 
made a comparative analysis of the interview texts possible. The separate interviews were divided into scenes, which were given catchwords throughout the various phases of analysis, which obtained a more and more abstract level. These catchwords were synonymous with certain aspects, the contents of which was again stored in elaborate 'memo's'. The applied research method is based on further development of the 'grounded theory' by Glaser and Strauss. It is linked up with the symbolic interactionism and tries, on the basis of the subjective perception of the social environment of those interviewed, to formulate inductive hypotheses and theories. There is no need for a great number of cases in this comparative research method (cf. Peters \& Wester \& Richardson 1989, 12-21; Maso 1987, 11-4/114-7; Van der Ven 1990, 130-7; 1993a; Glaser \& Strauss 1967; 1979; Lamnek 1988).

\subsection{Experiences with the religious socialization}

All seven interviewees have a great need for a system explaining usefulness, with which they can interpret life experiences, answer questions about the meaning of life and justify actions. Five of the interviewees described this system explaining usefulness, as a philosophy of life with a trascendental perspective. Two interviewees out of these five, attach great importance to the fact that this is a religious philosophy. Their faith in God and their church membership are, quite undoubtedly, important aspects of their lives. Religion and faith in God play a secondary part in the lives of the other five and the church even plays no part at all. They do indicate that they believe in God, but that they do not need an institutional organization to that end. In connection with the personal suicide crisis, four interviewees elaborate about their experiences with their religious socialization, without any requests from the interviewer. Three of these four women describe how they experienced the religious socialization during their childhood and adolescence as negative. The fourth interviewed person is positive about her religious socialization. The remaining three interviewees do not give spontaneous statements about experiences with their own religious socialization. However, it is striking that there is a great readiness with all the interviewees to pass religious meanings on to their children or allow others to do this for them.

In four of the seven interviews, the central issues are the personal experiences with the religious socialization during one's own childhood and adolescence, which has hardly lost any of its meaning to these women to this present day. Starting from the second research question, we will concentrate on these four case-studies from now on. As has already been indicated, three women report on very negative experiences and just one on positive ones, and where two of the four women explicitly state that they are consciously a member of the Roman Catholic church and find a hold and trust in their faith. One of them, Mrs S., in her mid forties, mother of several children and 
separated from her husband, judges her own religious socialization as very negative. Not until many years of religious abstinence had passed, did she rediscover the meaning of the church and her faith in God.

Mrs S.: 'Well, I believe that it has a lot to do with the parental home. At the time, they left me no room at all, as far as my faith was concerned, as well. On the contary, I had to go to church on Saturday nights, Sunday momings, Sunday afternoons and Sunday evenings. And I think, as a sixteen-year-old I also had other interests, apart from going to church. It ruined everything for me. I also had this anger which I could not handle and which then turned into pride. It was then that I said after I had got married: now I no longer intend to go. But at some point, I noticed that there was something missing. Yes, I think, one could say that. And then I obtained my attitude towards the church. [...] My parents were really very strict. At least, as far as I was concerned. I always had to go to church and in the afternoon I had to go for walks. I had no friend, because I just never got out. And I simply did not want to go for walks every Sunday, nor go to church every Sunday. I wanted to stay at home, as my brother was allowed to.'

Mrs G., mid sixties and alone, is far more positive about her religious socialization. She says that her faith has always been very important to her, from her childhood onwards. Her parents were very religious and saw to it that their five children would also grow up as faithful Christians. She is the only one, who, in principle, judges her religious socialization positively.

Mrs G.: 'My mother just acted by feel; she had lived on a farm, came from a Christian family of farmers; my father was far more critical, who often asked about the how and why of things. [...] He was also very open to modern matters; at one time he was also with the opposition. This has never interfered with his loyalty towards the church until he died.'

For the other two women, the church and religion have a whole new meaning today, in comparison with their childhood and adolescence. Mrs B., mid forties, married and mother of several children, says that, nowadays, she has lost touch with the church.

Mrs B.: 'Yes, in the past. My parents were very strict Roman Catholics, and as my husband does not belong to any church, I have only gone to church occasionally. [...] All three children have been baptized, because I wanted it, and have also made their first Communion and been confirmed. [...]'

Interviewer: You told me that you still attend Mass on occasion. How often does this happen?'

Mrs B.: 'Well, it was when the children were small that I used to go to church on Sundays and at Christmas. Later on, this barely happened.' 
Interviewer: 'Did you not have enough time, anymore, or did you not find it interesting?'

Mrs B.: 'No time, not uninteresting. But I think, you should not always run to the church. You can also do that at home.'

She grew up in a large family and as the fifth of nine children, she had to help out at home at a very early age. The evaluation of her socialization is very negative and, besides, can be interpreted against the background of her rather strict Roman Catholic parental home, as such that the Catholic moral rules and rules of conduct determined her entire childhood and upbringing. For example, after her wedding, her grandmother drummed it into her that, as a married woman, she would have to do everything for her husband, which was to have a very negative effect on her further development. Mrs B. describes her father as an authoritarian and strict man, whereas her mother did not have much say in matters, and had placed herself into a subordinate position. At the age of 17 , she met her present husband, whom she married soon afterwards, in order to get away from home, says Mrs B.. When linking up her next statement with her own rigid socialization, one has to admit that it is this religious socialization, in particular, that has prevented her fondest dreams and desires from being realized, because they, too, ignored the young girl's needs in favour of a casuistic moral code:

Mrs B.: '[...] what I have always longed for, is, what I never got at home, love, security and trust. These are the only things that have ever mattered to me. And I have never received these at home, nor in my marriage.'

Mrs M., also in her mid forties, married, mother of several children and who has, by now, left the Roman Catholic church, pictures her childhood and adolescence as quite positive. Opposed to this, her narrations about her religious socialization turn out very negative.

Mrs M.: '...Well, in inverted commas, I would like to say that my childhood has been very church-oriented.'

Interviewer: 'Roman Catholic or..'

Mrs M.: 'Roman Catholic. And the Roman Catholic, not the faith, but the Roman Catholic externals were an important item in our family. I am really convinced that it also included the faith for my parents. For us children, and I can partly speak for my brothers and sisters as well, everything remained somewhat on the surface. First of all, this was shown quite obviously in the regular church attendance and on Sundays we would naturally attend Mass in the morning, and go to Sunday school and in the afternoon to benediction (she laughs). In May we would frequently go the the May benediction and, once again, at night. The same in October, and in case we could not go, we would kneel down at home to pray the rosary. These were those externals.' 
Interviewer: 'Clear structures. Yes, yes.'

Mrs M.: 'Yes. And as I have said, as before, I think that it had the right background for my parents, and to us children it were the externals. And then with it, also came very clear guidelines, especially during puberty: This is all right and that is not. This is allowed and that is not. And girls have to be like this or that and there is no way to get round it, so I would say that we all felt quite restricted in our freedom of action. [...] So, although I could not become a priest, all such matters as the vow of chastity and the like applied to me, too. They were taken very very seriously and came first.'

At first sight, there are two matters to be noticed. First: Passing through negative experiences with regard to the personal religious socialization, is always linked up with an over-dimensional socialization by others. During their entire childhood and adolescence, the faith and religiosity of the parents has been forced upon the three women by the parents who had probably had to adopt it or had simply adopted it in their turn from their parents, without any critical exchange of thoughts. A will of one's own, one's own desires and dreams do not have a chance to develop. The women, in particular, had to yield to the religious and ecclesiastical standards and moral codes. There is not an exchange of views about the content. The fact that Mrs G. had positive experiences of her own religious socialization, shows that she had the opportunity to learn to come to terms critically with the faith and the religiosity. Secondly, this form of over-dimensional socialization by others is only possible on the basis of a way of upbringing and interaction, which, one-sidedly, emphasizes the socialization by others at the cost of the socialization by oneself. Or in other words: the way of upbringing and interaction that prevails here, distinguishes itself by a strict control and a negative or not available attention. It is striking, though, that this way of upbringing and interaction was not used consistently. The growing brothers of these women hardly have to suffer from the harassment of religious and ecclesiastical regulations. Girls and young women are subordinated to a stricter control that is independent of conduct, wheras the control dependent on conduct, which is very strict with boys and young men, is very little with them.

\subsection{Trace elements of the religious socialization in the suicide crisis}

The primary and secondary (religious) socialization produces socialization effects, which influence the human mind and, consequently, not just the actions of the girl (and boy) growing up, but also those of the adult women (and men). The question that interests us after the experiences of the women we have interviewed with their religious socialization, is about the trace elements of the religious socialization in their respective suicide crisis. 


\subsection{1 'Lack of options' due to the effects of the religious socialization}

For Mrs B., the main reason for her suicide crisis was the relational problem with her husband. Her husband will not speak to her for weeks. The marriage is a copy of her childhood: lovelessness and contempt of her person by her husband, respectively her father in the past. Her inability to decide against her husband and to persevere, and, at the same time, the intolerance of living together with him, leads Mrs B. to a dead end, where she is completely overtaxed and helplessly at the mercy of the situation.

Mrs B.: '...Maybe I should have persevered from the start. And have said something. But I had never said anything. At home, we were not allowed to contradict, neither my father nor my mother, and it was the same with my husband. My husband never agrees with me. And I mean, it was not easy for me. [...] And then I met my husband at an early age and at the time, I thought that it would bring me security and all. But it did not.'

Mrs B. fell from one dependency into another. She has not had any attention in her childhood and adolescence, nor in her marriage. Her dreams and desires remain unfulfilled: freedom and security. Due to a way of upbringing and interaction, which was characterized by a strict control and negative or missing attention, she never obtained a feeling of self-respect, respectively self-consciousness, and she never could develop personal talents. The result: a fully developed negative feeling of self-respect. The burdens became greater, her dreams and desires became more and more important. If it is true, that religions can help to prevent this chaos which threatens man, to control fears and to encourage hope, so that the crises of human life are bearable and can be survived (cf. Geertz 1991, 60-1; Zulehner 1976, 31), then the question arises, why people in their suicide crises do not (cannot) often fall back on their religious faith. Mrs B.'s religious socialization has contributed, on the basis of an inaccessible image of God, which has crystallized out in the course of the interview, and a strict casuistic moral code, to the fact that she does not have any options to break out of the cycle she has got herself into: she wants to leave her husband, who does not give her what she is looking for. On the other hand, she feels sorry for him, and has been brought up to put her husband's interests before those of her own. Only her children and her work, each give her support. She has toyed with the idea of taking her own life for years. It is only the care of her children that has held her back. As she does not find herself in a position to take independent decisions on her own, she has been waiting for years for her husband to change his conduct. At a certain moment, she has no strength left and tries to end this delicate situation. At this moment, she forgets her children and her colleagues at work; there is only one thing she wants: "No longer living this way'. Against the background of the history of her religious socialization, 
neither relgion nor faith can have a liberating meaning for her. On the contrary: she has learnt, enforced by a patriarchal and apathetic image of God, to surrender to her destiny. Although she has managed to shut out this image of God several times in the course of time, she has never succeeded in critically coming to terms with it.

The pursuit of harmony, tenderness and honesty also come first with Mrs S.. All her life, she has longed for harmony.

Mrs S.: 'Yes, it has always been this that I have been missing. [...] My husband was a cynic and I simply could not keep up with that. And then I felt so much a failure, that I could not restore this harmony. For myself. [...] My father has often refrained from speaking to me for eight or fourteen days, and I really had no idea why. And I think that my marriage was a repetition. My husband spoke with me, but I could not understand his language, at all.'

She blames herself for her marriage problems. She also takes responsibility for her husband's drinking problem. After four years of marriage she contemplates divorcing her husband for the first time, because he constantly deceives her with other women. Yet, an inner strength holds her back. This strength is fed by her upbringing, that a marriage has to last until death parts husband and wife. Since her childhood, she has not had any scope to develop her personality from her parents nor her husband. She is helplessly at their mercy. At the age of 14 , she tries to draw attention to her desperately restricted freedom of action, for the first time:

Mrs S.: 'We went for a walk in the wood, and I know, that my mother had often told us that these berries were poisonous. Well, and I simply ate these berries. Then, I also wanted, I absolutely wanted to die, even then. I was also desperate then, that I did not have any freedom of action for myself, that I could not take any decisions. And that is the way I felt at the time, as well. I simply could not decide, yes, my husband decided for us. Yes. I felt unable to take a decision. Although I was an adult human being.'

During her second and last attempt to harm herself, she took an overdosis of pills. She could not go on: her husband's drinking problem, often linked up with aggressiveness, social decline, because her husband had lost his job, the upbringing of three children, and no one she could openly talk to. She faces problems which she cannot solve, she feels guilty and is hopelessly desperate. She does not think she actually wished to die. She only wanted to sleep and rest. In the depth-psychological literature, self-denial is regarded as the main reason for most of the different forms of neurosis. By means of the mechanism of separation, the hatred of God, the parents, the grandmother or the husband, respectively the wife, is shut out and is unconsciously directed towards oneself. In her interview, Mrs S. brings this process to the point: 
'Then I also had this anger, I could not use, which then just resulted in pride [...].' Mrs S. also grew up with a way of upbringing and interaction, which was marked by a strict control and just a moderate or missing attention. What she obtained was not self-confidence, but self-denial and selflessness, by means of which she learned helplessness and the example of attribution to feel guilty about failures. There was also little opportunity for developing any talents. Her consciousness of guilt penetrating everything, her desire for harmony and her inability to see through the situation, point to clear traces of a mismanaged interpretation plan. In this case, the religious socialization also leads to a lack of options. However, Mrs S. has succeeded to come to terms with her life-story and her religious socialization in the course of time. She can distance herself from the apathetic and strict image of God of her childhood and adolescence. She gradually manages to create an image of God that is humanly-friendly, and which supports her self-confidence and creates talents and opens new possiblitities to find one's own meaning of life.

In the case of Mrs M., the cause of her crisis is a protracted illness. After a stay in hospital, she can no longer gain a firm foothold in her everyday life. She feels physically and mentally broken. Her weariness of life is increasing, although she has only recently escaped death. She starts to occupy herself with her life so far, and tries to come to terms with her childhood and to put her life in order. Problems with her eldest son, communication problems with her husband and a triangular relationship constantly put pressure on her to take a decision. She says that she has never been good at taking decisions. She always fears to decide in favour of, or against, something. In addtion, she has demanded a very high level of perfection of herself since her childhood.

Mrs M.: 'I also remember myself as being a very ugly child. [...] And my sister was always terribly charming. So, next to her $I$ really felt foolish (she is laughing) and I have ever since, even as a child, developed a tendency towards doing everything in a super and perfect way, in order to get a kind of justification out of it. It is as if there is also a point there to feel constantly guilty, which is a feeling I still have. And I am terribly sensitive to criticism of whatever nature.'

In the most literal meaning of the word, Mrs M. looses control. She follows an inner urge to escape from this tangle and attempts spontaneously, though consciously, to commit suicide by taking an overdosis of pills and alcohol. Mrs M. is discovered in time and is taken to hospital. During this period of time, her husband concerns himself a lot about her. What she had missed until then, she says, was given to her at that time: recognition. support and attention. For the first time, her husband had really been there for her. Mrs M.'s case has clear parallels with the first two cases. A rigid way of upbringing and interaction (strict control and missing recognition) marks the 
(religious) socialization. A feeling of self-respect, self-consciousness and the development of talents are hardly possible. In comparison with boys, girls are clearly dscriminated against. Consequently, adult women have a negative self-image and a negative balance of expectations, respectively their competence of action. They demand too much of themselves and are hardly capable of taking their own decisions. They do not find what they are looking for. But what they are looking for, becomes more and more important and increasingly existential to them. If the burdens rise to the limit of their physical strength, they cannot resist it. Strategies to solve problems are hardly available, or there are no positive results to be anticipated. At first, the women wait. They have learnt passivity and helplessness. Their attempts to draw attention to themselves and their problems, fail, because they are not heard and/or do not dispose of adequate means of communication. The effects of the religious socialization are co-causers of the incompetence of action as described here: the obtained image of God does not have a liberating, but a damaging effect. It leads women to their dead ends of feelings of guilt and worthlessness. When Mrs M. tries to free herself from her religious socialization by leaving the church, she has cut off the stem, but has preserved the roots.

\subsection{2 'Search for possibilities' with the help of the effects of the religious} socialization

The case of Mrs G.'s crisis has two main points: At the top of her professional career she becomes that ill, that she has to quit her job. However, she completely fails to come to grips with it. For the first time, she feels depressive feelings springing up within her. When, in addition, she started to suffer from a severe eye disease a few years ago, she dropped into a heavy depression.

Mrs G.: 'The depression came when it started. But, you know, it was actually a real life crisis, looking back on it now. It was not just because of my eyes, but it was the final provocative moment. I suddenly had this view: What is it that you have really accomplished? You have had to leave school at a relatively early age. It is true that you have then had a lot of private education. [...] I have been through rather a lot. I had an accident as a pupil, ending up with a deep scar on my leg, and then I was always very nervous, became ill very quickly, then there was this intestinal infection, which no one recognized, there had hardly been any research on this disease, and all its consequences. On top of that, there was this eye illness.'

Thoughts about suicide occur in her mind again and again. Although she does not plan a suicide at any specific time, the thought that she could free herself from all suffering by taking an overdosis of medication, is very familiar to her. She seeks professional help. She feels misunderstood as a religious woman by two doctors. It is very imporant to her that the doctor or 


\section{EFFECTS OF RELIGIOUS SOCIALIZATION ON SUICIDE}

therapist in attendance accepts her as a faithful Christian. By accident, she finds out the address of a consultancy for religious questions and questions of life and death, that can help her further. Looking back, she believes that it was not just her doctor, but also her own circle of friends and a few theologians, who helped her at the time of her deepest depression to find a way out of her preponderant depressive mood and to regain her courage to live. While coming to terms with her religious questions and the questions about the meaning of life, she gradually learns to value the Eucharist and the Adoration, despite rational objections.

Mrs G.: 'And I said, well, this father said to me, among other things, perhaps the Eucharist can help you to deepen your faith when you have doubts about it. Then I told him that this would happen sooner, anyway, with someone who had had an education. And there is a lot of truth in that. I became aware that this was good for me. It does not remove various doubts, but it feels right. And I just cannot believe that I have come out of it on my own. And, therefore, I assume that people have prayed for me, and are still praying for God to help me, for I am convinced that this did not come out of myself.'

Mrs G.'s case is different from the first three cases, not only because she has not attempted suicide, but mainly, because she could deal with her crisis situation in a completely different way. On the basis of the way of upbringing and interaction by her parents (positive attention and average to strict control), she was able to develop a feeling of self-respect, self-consciousness and talents. Equipped with these, she is better able to meet the burdens of her diseases, that means, she can arrange the origins more realistically and apply specific strategies to solve the problems. According to her information, it was her father who taught her a critical, but basically positive attitude towards faith, church and religion. This is how she established a confident relationship of faith with God, which she could hold onto, despite all terrible ordeals, by means of critical reflections and develop further. It is only on this basis that in this crisis, she can find comfort and strength in her faith in a sympathetic, immanent-transcendental God. In all, one can say that the effects of Mrs G.'s religious socialization, encourage the process of searching for the meaning of life, of further possiblities to cope with the situation, adequately.

\subsubsection{Conclusion}

The religious socialization exercises an influence on the suicide crisis by means of its socialization effects. This does not happen in a direct way, but in an indirect manner in a combined action with physical, psychological and social factors, which play a decisive part in the development and the expansion of the physical and mental opportunities in life, respectively possibilities 
of action for the individual. These, again, are conditions for an adequate handling of crisis situations, in which problems surpass the psychological strength in the form of exceptional burdens and the common stategies for solving problems. This lack of possibilities can be described as tragic, as it contributes to people's destiny regarding its existential meaning and is, on the one hand, to be overcome in principle, respectively, not necessary, and, on the other hand, cannot be changed as it lies, again, outside of their possibilities. Finally, it is partly about an individual-human product and partly a social one. In the research that is discussed here, we could show that the religious socialization, in simplified terms, exercises both an influence leading to suicide and one preventing suicide. On the one hand, the effects of the religious socialization (religiosity, image of God and man, self-consciousness) contribute to the lack of possibilities leading to the suicide crisis, which cannot observe situations and actions completely, interpret them realistically or take actions in accordance with the problems. On the other hand, they demand the search for opportunities, to solve the problem adequately, by supporting the critical openess for a process of discovering the meaning of life. In short: religious socialization can block and/or inspire.

\section{The religious socialization and the suicide crisis: practical-theologi- cal evaluation}

In the final paragraphs there will first be a methodological evaluation of the research under discussion (3.1), before drawing some practical-theological conclusions for suicide-prophylactic measures from the research results (3.2). The future of the pastoral practice in the field of the suicide prophylaxis, is the end of this article (3.3).

\subsection{Methodological evaluation}

In this case, it is, of course, a retrospective research, which not only tries to reconstruct the personal condition before the attempted suicide, but, far beyond that, falls back on the childhood and adolescence. The objections saying that the validity of the obtained information diminishes with the advance of the time difference in relation to the experiences people have been through, cannot be removed, but can still be put in perspective on two points. As has been demonstrated in paragraphs 1 and 2, early-childhood and adolescent experiences are of such crucial importance to a person, that it is absolutely necessary that they should be involved, even in retrospect, as a background of experience in diagnostic researches. According to the Thomastheorem, this is also quite meaningful, since it departs from the assumption that the personal definition of the situation is decisive for people's actions, instead of the 'objective' situation. Moreover, the suicide problem brings 


\section{EFFECTS OF RELIGIOUS SOCIALIZATION ON SUICIDE}

with it that the research into these problems depends on retrospective investigations. Besides, it should be pointed out that in the suicide research, such retrospective information also has a prospective character. On the one hand, it can be statistically demonstrated, that people often try again to commit suicide, after they have carried through a single or several suicide attempts. On the other hand, it is important to know why people have not attempted (another) suicide (cf. Rausch 1991, 62; Diekstra 1983, 62; Maso 1987, 63-71).

Even though the theoretical explanations and supplementaries of the empirical random indications have to remain, at first sight, unfinished and incomplete, this research has attained its objective, anyway, namely to make a contribution to the development of a theory of the suicide prophylaxis from a practical-theological perspective. It is one of the pastoral tasks to observe people's destiny, to pass on God's nearness through human nearness, to take the problems seriously, to lift up man and to support him in his process of self-development. The religious socialization internalizes a critical religiosity, which supports the development of a self-respect, self-consciousness and talents, irrespective of it happening during the primary or the secondary socialization phase. In this sense, the religious socialization is a basis for a 'salvation bringing' faith in the God Jesus who loves man, who implicitly accepts and ackowledges each single person and is, thus, an excellent prophylaxis for a crisis of life (cf. Baumgartner 1992, 43-7). In general, religions can be 'roads of phantasy' (Van der Lans 1994), on which people can find the strength and the opportunity to explain fundamental experiences and to give them a meaning. In case these 'roads of phantasy' disappear, an important inspiring factor vanishes at the same time, which offers man to come to terms with the questions of the meaning of life and of being human in a transcendental and open way (cf. Hole 1977).

In private life, religion still holds an important position for many people, but for a long time, it has socially merely had a marginal meaning. What would have been inconceivable in the past, has become more and more common: children mostly grow up without any religious socialization. It would be cynical to suggest that, in view of the bitter experiences which many people have had with their own religious socialization, they can call themselves lucky to have been born in a time not determined by religious forces. Yet, despite all justified criticism on the denominational religiosity and restricting, rigid religious socialization, it should also be observed, on the basis of the findings of this research, that the children are withheld an opportunity to shape their lives in a more open, more critical and more human way. This article intends to be a plea in favour of a critical acquaintance with and an introduction into a dimension, which goes beyond our human horizon and is oriented towards that which the Christian faith defines as God's love, which 
offers man self-respect, the opportunity to accomplish himself humanly and meaning and, thus, salvation to his life.

\subsection{Suicide prophylaxis from a practical-theological perspective}

In this article, we have tried to establish the meaning of the religious socialization for the suicide crisis, and, thus, in an indirect way also for the suicide prophylaxis. By means of four case-studies, we could demonstrate that the religious socialization prior to and during a suicide crisis can have an important influence on the personality and the competence of action. The considerations under discussion should be regarded as a contribution to the discussion, which wants to introduce the practical-theological point of view into the modern suicide research. The task of the Practical Theology for the connection described here, is to accelerate the establishment of a theory regarding the support of the adolescent and the self-destroying person in the whole process of finding himself and the meaning of his life. Looking back upon the establishment of this theory, which is ultimately at the disposal of the pastoral practice, it will always be irrevocable to investigate the actual connections of reality in an empirical-theological way. For the development of a practical-theological perspective for the establishment of a theory on the suicide prophylaxis, we lean on the three forms of suicide prevention, which are used in suicidology (cf. Diekstra 1981, 223-60). The following picture results from this:

\subsubsection{Primary prophylaxis}

The primary prophylaxis which occupies itself with the prevention of the development of suicidal tendencies in society and with the individual, is still the least investigated and most difficult area of the suicide prophylaxis. It is focussed on both the primary and the secondary socialization. The way of upbringing and interaction is naturally at the centre of the primary socialization phase. Reliable structures, unlimited acceptance and support can give the adolescent certainty, security and courage with regard to his own steps. More factors are added in the secondary socialization: education, leisure activities, habits of consumption, choice of profession, work satisfaction, individual and social climate and much more. The effects of the religious socialization could also work in a prophylactic way: an image of God that furthers the feeling of self-respect, the joy of life and existence and the constructive critical competence, so that crisis situations do not even arise or can be reflected upon in a better way. The main task lies with the parents or the second educators. They should pass on their faith in a God who is kind to man, to the child in their care in a convincing way, by means of stories and by using their behaviour as an example. To this end, there should be new main pastoral issues. Family and elderly works/children and adolescent 
works; religious-communicative competence and encouragement of parents regarding the effect of images of God and man, confrontation and explanation with existential themes, such as, tragedy, death and guilt.

Girls and young women are particularly affected. Their feeling of self-respect is severely undermined by the traditional way of upbringing. It is not surprising that the four case-studies are presented by four women. Women, respectively girls, in particular, are treated more severely than boys. From their earliest childhood, they are taught to restrict themselves and that there are many things they are not allowed to do. On the contrary, in the case of boys, a relative autonomy is defended and promoted from the beginning (cf. Nuber 1992). Adaptation and subjection to a will from outside intensively prevent, as we have seen, the psychological and physical independence. In this way, through their upbringing, young girls obtain a helplessness, which is oppressive to many women. This conduct will restrict and burden them for the rest of their lives (cf. Swientek 1990, 57-66).

From a practical-theological perspective, there is, prophylactically speaking, a completely unexplored field in the area of religious social welfare work, individual pastoral care and the care of groups, but also within the reach of the foundation of a community. Children's, juvenile and adult works can pass on self-respect and self-consciousness on the level of the secondary socialization in the pastoral care and the care going beyond the parish, and thus contribute to the richness of talents. Here, the religious socialization should be regarded as a help in developing the individual and, thus, man.

\subsubsection{Secondary prophylaxis}

The secondary prophylaxis treats the acute interference with people threatened by suicide, as crisis intervention. Since the people who are looking for help at this stage, are usually acutely threatened by suicide, the church workers should ask themselves to what extent they can meet this task, and at what stage they should pass these people on to professional psychologists, psychotherapists and the like, who are specialized in suicide problems (cf. Reiner 1990, 327). Within a certain context, they can try, without trifling with the crisis problem or even denying it, to intervene in a 'pastoral' way. 'Pastoral Counseling' could be a form of pastoral intervention for the secondary prophylaxis. At the centre is God's acceptance of man and the restricted image of man, due to transcendental poverty. This type of pastoral care, focussed on speech, could succeed in guiding people in their process of finding themselves and the meaning of their lives, and, thus, to support them on their way towards the establisment of their individuality. This way they could, relying on God's acceptance, gradually take over the destiny and control of their lives themselves. After all, Pastoral Counseling is about 
contingency counseling, meaning that counseling involves both guidance and offering help. It is a kind of guidance, which helps people to deal with their contingency and their finiteness in a human way. It should help them to express themselves on this matter, so that they will be able to assign a place in their feeling and their mind to their fears and desires. This can be about the experience of the physical finiteness of one's own life, or about the experience of the non-removable relational and social boundaries here and now (cf. Van der Ven 1991,117).

\subsubsection{Tertiary prophylaxis}

The tertiary prophylaxis pays all its attention to people after an unsuccessful suicide attempt. People who have once tried to harm themselves, are regarded in suicidology as greatly threatened by suicide. If there is not an important psychological illness, the psycho-social aftercare, respectively tertiary prophylaxis, starts at the hospital bed and is continued on a regular basis, bounded by time. In the field of the tertiary prophylaxis, there is a, though not large, yet a very important work area and set of tasks for the church workers. In this article we have tried to point out, that the suicide crisis should be seen as an individual lack of possibilities. In Pastoral Counseling, the church workers have the opportunity to break through this life-threatening cycle by means of communication. Basically, it also means, that the origins and reasons for a suicide crisis should not be trifled with or denied. The tertiary prophylaxis is the road of the many small steps, which themselves can lead to a dead end, in case the physical, psychological and social factors, which play a role in the suicide crisis and its genesis, are ignored. Pastoral Counseling must not become spiritual therapy, which only corrects, but does not cure. It must not block or prevent necessary psychotherapeutic treatments. The co-operation and collaboration with doctors, psychologists, psychotherapists etc. is an important precondition for that. The meaning of Pastoral Counseling in the sense of the above description of contingency counseling is, passing on God's salvation, which is present in the whole acceptance of the human being as it is, and in the release from the human self-destruction. Salvation and recovery are inseparably connected, just like self-experience and the experience of God, the establishment of oneself and the discovery of God (cf. Funke 1993, 46-58).

\subsection{Future perspective}

In connection with all justified considerations, one should not overlook the fact, that the religious socialization in general, and the Christian transfer of faith in particular, have lost in importance and effect. The roots can be found in an increasing secularization and pluralism of modern western society, but also in the fact that the church workers are not entrusted (anymore) with this 
profession. Christianity has been robbed of its monopoly position and has to tolerate other religions, non-religious world views and also systems explaining the meaning of life without any world view, such as familialism or consumptionism (cf. Van der Ven 1993, 138-9). It should furthermore be said that, genuine religious themes in origin, such as suffering, death and guilt, no longer fit within the modern westem consumption and performance society and are pushed aside. In times of a (ecological, social, economical, political) crisis, as we have at present, people are all the more confronted with them and experience them as often as an unbearable threat (Richter 1992). Sometimes, the question about the meaning of life is reconsidered on an individual level, and with it, the questioning of the faith in the human omnipotence. All this naturally influences the function of religion in society. Whereas it used to play a crucial role in social life, it has now been driven with its issues to the borderline of social interest. Religion has been relegated to a private affair and serves as a practice of triumphing over contingency in individual problem cases (cf. Mette 1978,76).

The search for the meaning of life and the triumph over contingency are both directly linked up with a certain openess towards Trascendence. It is not denominational religiosity, but the transfer of the Christian faith through contact persons, who convincingly live their faith, that is needed. Although many parents want their children to be socialized in a Christian way, to ensure that they obtain the possibility to put a meaning to their lives, they are not trustworthy intermediaries. This is also true of ecclesiastical office holders and professional church workers, whose words and actions often do not agree. If a religion does not want to operate marginally only, it should convincingly enable people to confirm themselves and God. If this development is suppressed, or in case religion promotes the second item without encouraging the first, it should consequently move to the borderline of social interest. Not until a person has experienced the development of a feeling of self-respect, does he find himself in a position to observe his, albeit dependent, freedom and to take decisions at large.

The fact that it is, in particular, the religious socialization which is the foundation for the sympathy of fellow men and for seeing the world as a meaningful and social reality, makes it clear what opportunities can be connected with it. Especially in this area, the first relations of the individual with the social world and the image of God are established. A reality is internalized, which cannot be avoided. Religious rules of conduct, moods, motivations and convictions, transferred by parents and, possibly, church workers have a special quality as a binding cultural sample for the child in his development at the stage of the primary socialization. 'It will be of overriding importance, whether the Christian individual succeeds in socializing this form of religious individuality in a lively way, in incarnating it in 
an illustrative way and in making it manifest at the centre of man's struggle and man's history.' (Metz 1977, 65). Should religious socialization be successful in this respect from the age of an early child onwards, it could transfer a true passion for being for finding the meaning of life and, thus, the possibilities of life.

\section{LITERATURE}

Bandura, A. (1979). Sozial-kognitive Lerntheorie. Stuttgart.

Baumgartner, I. (1992). Heilende Seelsorge in Lebenskrisen. Düsseldorf.

Berger, P.L. (1980). Der Zwang zur Häresie. Religion in der pluralistischen Gesellschafi. Frankfurt/M.

Berger, P.L. \& Luckmann, T. (1987). Die gesellschaftliche Konstruktion der Wirklichkeit. Eine Theorie der Wissenssoziologie. Frankfurt/M.?

Diekstra, R.F.W. (1973). Crisis en gedragskeuze. Een theoretische en empirische bijdrage tot het zelfmoordprobleem. Amsterdam.

Diekstra, R.F.W. (1981). Over suicide. Zelfdestructie, zelfbehoud en hulpverlening. Alphen/Rh.Brussel.

Diekstra, R.F.W. (1984). Suïcidaliteit en hulpverlening. In: idem (red.). De zelfgekozen dood. De problematiek en de hulpverlening. Baarn, 46-90.

Dömer, K. \& Plog, U. (1992). Irren ist menschlich. Lehrbuch der Psychiatrie/Psychotherapie. Bonn?.

Funke, D. (1993). Der halbierte Gott. Die Folgen der Spannung und die Sehnsucht nach Ganzheit. München.

Geenz C. (1991). Dichte Beschreibung. Beiträge zum Verstehen kultureller Systeme. Frankfurt/M. ${ }^{2}$

Glaser, B.G. \& Strauss, A.L. (1967). The Discovery of Grounded Theory: Strategies for Qualitative Research. Chicago.

Glaser, B.G. \& Strauss, A.L (1979). Die Entdeckung gegenstandsbezogener Theorie: Eine Grundstrategie qualitativer Sozialforschung. In: Hopf, G. \& Weingarten, E. (eds.). Qualita. tive Sozialforschung. Stuttgant, 91-111.

Grom, B. (1992). Religionspsychologie. München-Göttingen.

Hole, G. (1977). Der Glaube bei Depressiven. Religionspsychologische und klinisch-statistische Untersuchungen. Stuttgart.

Jaschke, H. (1992). Dunkle Gottesbilder. Therapeutische Wege der Heilung. Freiburg/Br.

Lamnek, S. (1988). Qualitative Sozialforschung. Bd. 1 Methodologie. München-Weinheim.

Lans, J.M. van der (1994). Religiöse Universalien in der Psychologie des Selbst. In: Ven, J.A. van der \& Ziebertz, H.-G. (eds.). Religiöser Pluralismus und Interreligiöses Lernen. Kampen-Weinheim, 71-85.

Maso, I. (1987). Kwalitatief onderzoek. Meppel.

Mette, N. (1978). Kirchliches Handeln als 'Kontingenzbewältigungspraxis'? Zur Diskussion über die kirchlich distanziente Religiosität. In: Bertsch, L. \& Schlösser, F. (eds.). Kirchliche und nichtkirchliche Religiosität. Freiburg/Br., 70-87.

Metz, J.B. (1977). Glaube in Geschichte und Gesellschaft. Mainz.

Oberthür, R. (1989). Angst vor Gott? Über die Vorstellung eines strafenden Gottes in der religiösen Entwicklung und Erziehung. Essen.

Nuber, U. (1992). Mädchen: Immer noch zuviel Anpassung. Psychologie heute. 19/4, 66-71.

Peters, V.: Wester, F. \& Rjchandson, R. (1989). Kwalitatieve analyse in de praktijk en Handleiding bij Kwalitan versie 2. Nijmegen. 


\section{EFFECTS OF RELIGIOUS SOCIALIZATION ON SUICIDE}

Rausch, K. (1991). Suizidsignale in sozialen Interaktionen - und Auswege in der Therapie. Regensburg.

Reiner, A. (1974). 'Ich sehe keinen Ausweg mehr'. Suizid und Suizidverhütung. Konsequenzen für die Seelsorge. München-Mainz.

Reiner, A. (1990). Seelsorgliche Beratung und Begleitung für besondere Lebenssituationen. Bei Suizidgefährdung. In: Baumgartner, K. \& Müller, W. (eds.). Beraten und Begleiten. Handbuch für das seelsorgliche Gespräch. Freiburg/Br.-Basel-Wien, 321-31.

Richter, H.-E. (1992). Umgang mit der Angst. Hamburg.

Ringel, E. (1989). Selbstmord. Appell an die anderen. München'.

Schlette, H.R. (1966). Kirche unterwegs. Olten.

Schmidtchen, G. (1989). Schritte ins Nichts. Selbstschädigungstendenzen unter Jugendlichen. Opladen.

Schmidtke, A. (1988). Verhaltenstheoretisches Erklärungsmodell suizidalen Verhaltens. Regensburg.

Schmidtke, A. \& Schaller, S. (1992). Verhaltenstheoretisch orientierte Therapiestrategien bei selbstschädigendem und suizidalem Verhalten. In: Wedler, H.; Wolfersdorfer, M. \& Welz, R. (eds.). Therapie bei Suizidgefährdung. Ein Handbuch. Regensburg, 99-121.

Swientek, C. (1990). Wenn Frauen nicht mehr leben wollen. Reinbek.

Tillich, P. (1975). Wesen und Wandel des Glaubens. Weltperspektiven. Frankfurt/M. - Berlin Wien.

Ven, J.A. van der (1990). Entwurf einer empirischen Theologie. Kampen-Weinheim.

Ven, J.A. van der (1993). Ecclesiologie in context. Kampen.

Ven, J.A. van der (1993). Die qualitative Inhaltsanalyse. In: Ven, J.A. van der \& Ziebertz, H.-G. (eds.). Paradigmenentwicklung in der Praktischen Theologie. Kampen-Weinheim, 113-64. (1993a)

Zulehner, P.M. (1976). Heirat, Geburt, Tod. Eine Pastoral zu den Lebenswenden. Wien.

The first author holds a Master's degree in Theology and is a staff member of the department of Practical Theology at the Catholic University Nijmegen. The second author is professor in Practical Theology. Their address is: Catholic University, department of Practical Theology, Erasmusplein 1, 6525 HT Nijmegen, The Netherlands. 